\title{
THE ROLES OF STATE RELIGIOUS CONSELORS IN PROMOTING PEACE AND HARMONY IN AMBON CITY
}

\author{
PERAN PENYULUH AGAMA DALAM MEMPROMOSIKAN \\ PERDAMAIAN DAN HARMONI DI KOTA AMBON
}

\author{
Muhammad Rais \\ Balai Penelitian dan Pengembangan Agama Makassar \\ Jl. A.P.Pettarani No.72 Makassar \\ Email: raispuslit2@gmail.com
}

Naskah diterima tanggal 22 Maret 2016. Naskah direvisi tanggal 28 Maret 2016. Naskah diterima tanggal 3 Juni 2016.

\begin{abstract}
The aim of this research is to describe about the performances of religious conselor, a conselor who has a strategic role and position as State Civil Servant, who is on the front guard in giving religious services to the general public. A religion counselor is a representative of Indonesia Ministry of Religious Affairs that got the constitutional mandate to deliberate society's needs related to the development in the religious field, especially in the field of conseling that uses 'religious language'. Through the qualitative method used in this research, the social realities concerning religious conselor's performance and contribution in managing the living harmony among religion believers in Ambon City could be described effectively. For the context of Ambon City, the characteristics were relatively specific as this region was in the category of high level conflict potential; so it was necessary that there should be Civil Servants who had the performances and capabilities in portraying the public socio-cultural condition. Therefore, what became the priority for the context of Ambon was the reinforcement of each religious conselor's capacity to carry out his conseling activities and to be proactive in the process of managing the living harmony among religion believers.
\end{abstract}

Keywords: Performance, religious concelor, living harmony, Ambon

\begin{abstract}
Abstrak
Penelitian ini bertujuan untuk mendeskripsikan kinerja penyuluh agama yang memiliki posisi dan peran strategis sebagai Aparatur Sipil Negara yang berada di garda terdepan memberikan layanan keagamaan kepadapublik. Sebagai representasi institusi Kementerian Agama yang mendapatkan mandat konstitusional mendeliberasikan kebutuhan masyarakat terkait pembangunan di bidang agama, khsususnya di bidang kepenyuluhan dengan memanfaatkan bahasa agama. Melalui metode kualitatif yang dimanfaatkan dalam penelitian ini, realitas sosial berkenaan dengan kinerja penyuluh dan kontribusinya dalam tata kelola kerukunan di Kota Ambon dapat dideskripsikan secara efektif. Untuk konteks Kota Ambon, relatif memiliki karakteristik tersendiri, wilayah ini masuk dalam kategori tingkat potensi konflik yang tergolong tinggi, sehingga dibutuhkan aparatur sipil yang memiliki performa dan kapabilitas yang mampu memotret kondisi sosio-kultural masyarakat. Maka yang perlu menjadi prioritas untuk konteks Ambon adalah penguatan kapasitas para penyuluh agama dalam melakukan penyuluhan dan proaktif dalam proses tata kelola kerukuman umat beragama.
\end{abstract}

Kata Kunci: Kinerja, performa, penyuluh agama, kerukunan, Ambon

\section{INTRODUCTION}

$\mathrm{T}$ he domain of this research for policy. In the scarcity of literature that specially studies policy research specifically, it is certainly inevitable to find that nobody is better able than Ann Majchrzak in defining this method of research as, "....therefore, is defined as the process of conducting research on, or analysis of, a fundamental social problem in order to provide policymaker with pragmatic, nation-oriented recommendations for alleviating the problem"-(quoted by Riant Nugroho, 2014 , p. 46). Frequently lies in a deductive frame that in a top-down way derives a regulation to be evaluated regarding the implementation 
effectiveness of a program/activity that becomes the Government regulation formulated in detail in vision and mission. In the context of the government policy performance in religion development, Ministry of Religious Affairs as the Government representative constitutionally supports this authority.

One of the elements in organizational unit that lies in a strategic position, because the provider of services is on the front guard in giving services, is the religion counselor who becomes a barometer of work achievement and quality of the Ministry of Religious Affairs in a macro way (syumuliyah). An entrance door for the general public as the clients/ consumers to judge the performance level of this ministry, religion counselor as a "door crossbar" really interacts directly with his fostered or supervised group.

The strategic position of religion counselor in a legal way or dejure has also been regulated in several regulations, such as: the Joint Decree of the Coordinating Minister of Development Supervision and the Minister the State Apparatus Control Number 54 Year 1999 about the Functional Position of Religion Counselor, that religion counseling is an activity to give guidance and counseling in the fields of religion and development by using "religion language" to foster the role of society in national development, connected with the Joint Decree of the Minister of Religious Affairs and the Head of State Officials Administration about the Operational Procedure of the Religion Counselor Position, Article 1, Verse (1): Religion Counselor is a Civil Servant assigned, responsible, authorized, and fully entitled by the Authority to carry out activities of guidance, counseling in the fields of religion and development by using religion language.

The encountered problem concerning the position of religion counselor as the front-liner provider of services, from the regulation context to infrasstructure that are oftentimes irrelevant with the actual public condition of society who has been more aware of their true rights and needs given by the State. Ambon City, for instance, is part of the ring of fire category, where the potential of latent conflict and its communal manifest are very strong. So, to respond to such a public reality, it has become absoluteness for stakeholders to be proactive in encouraging the invention of social harmony by empowering their apparatus on site, such as the religion counselors.

Research problem, referring to the description about the religious social reality and the position of the Ministry of Religious Affairs institution as described above, especially the tasks and functions of religion counselors as State Civil Apparatus on the front guard in giving religious services, the significant thing that needs to be given constructive solution through this research is: how the performance of religion counselors should be in giving services in the field of development, including their involvement in managing the religion believers living harmony in Ambon City?

Aims of research therefore, this research was projected to describe the religion counselor's performance as the provider of public services who are truly to be given the services that are in line with the public needs (public demand driven), and based on an environment context. And when speaking about the context of Ambon City whose social configuration is quite segregated, which in a latent way -considered to be still keeping a conflict potential where religion counselor should truly play a role in creating religion believers living harmony. This role becomes very significant considering the very strategic position of religion counselor that is on the front guard in representing the institution of the Ministry of Religious Affairs, both from the sides of institution and performance.

Output of research. Result of research that contain constructive solution, is one of the expected outputs, through this research the decision-makers in the Ministry of Religious Affairs institution have scientific references in making decisions related to the reinforcement of religion counselor's capacity and performance which are not yet optimal for the context of Ambon that still has a pretty high conflict potential, is truly to be the task domain and one of the functions of religion counselor related to the management of believers harmony that becomes a strategic interest at the local level.

\section{Literature Review \\ Religion Counselor's Performance}

Counselor in Islamic lexicology is known with the concept of al-da'i (caller, preacher and broadcaster, to invite, to call, and to appeal) to Islam. This concept/activity involves three main elements, including: 1) giver of message, teaching, information that is communicated, and 2) receiver of message. This concept has a meaning which is almost similar to the concept of tabligh and bashirah. (Muhammad Munir, 2012, p. 19). Besides the concept of $d a^{\prime} i$, in the counseling activities, the term counseling semantically has the same meaning as the concept of 
irsyad in the management of dakwah. The concept of irsyad is understood by Al-Khuli as, "al-taujih nafsin yusa'idu al-fard 'ala halli musykilat" (counseling or guidance of a counselor for his clients or counseling to help solve existing problems), (quoted from Saiful Akhyar Lubis, 2007, p. 30)

Arthur J.. Jones (Saiful, 2007; 32), uncovered the meaning contained in the concept of counseling as, "denotes a professional relationship between a trained counselor and client. This relationship is usually person to person, although it may sometimes involve more than two people, and is designed to help the client understand and clarify his view of his lifespace so that he may make meaningful and informed choices consonant with his essential nature in those areas where choices are available to him."

The above concept contains the meaning that counseling activities involves relation and interaction between counselors and people or the general public, where some of them act professionally as counselors or $d a^{\prime} i$ who have been well-trained with the clients or public that they serve. The purpose is to help the clients and people to find, understand their true meaning of life and encourage them to make choices in their life.

\section{Living Harmony}

Mukti Ali, the Minister of Religious Affairs in the New Order era, with his colleagues from circles of non-ideological Islamic patron figures, was known as the initiator of the believers harmony idea, (Mujiburrahman, 2008: 252) an idea that was projected in order for religion believers to work hand in hand to support the development program that became the agenda and vision of the New Order.

\begin{abstract}
"Politics of Harmony" according to Mursyid Ali was a form of social mechanism which was programmed by design, for example to support the establishment of a council for religions, to form a medium of inter-believers association, to develop an understanding among religious leaders and figures through a variety of meetings and contacts among individuals, and also to develop regulation instrument that functioned to prevent the use of religion as a reference system until the conflict level.
\end{abstract}

The "politics of harmony" program for a period of more than three decades according to Abdurrahman Wahid (2004:3), developed in various dimensions of inter-believers relationships in Indonesia, which qualitatively changed, and was at the same time influenced by the development of religious thoughts among the religion believers themselves.

\section{METHOD OF RESEARCH}

The genre of research. Research for policy which was more pragmatic became a paradigm in the frame of describing the performance of religion counselor in Ambon City by using qualitative method, data and information regarding analysis units of this research that were obtained through some instrument or mechanism, including: in-depth interviews, observations and studies of relevant documents.

Technique of data collection. also on the qualitative-deductive basis, informants were chosen purposefully based on the needs for data in the research locus. Regarding the main informants who were assumed to have adequate information data related to counseling, they were arbitrarily chosen from Civil Servants, who were Muslim, Christian, Catholic, Hindu, and Buddhist, Head of the Ambon City Office of Ministry of Religious Affairs, Head of the Islamic Broadcasting Section in the Regional Office and in the City Office of Ministry of Religious Affairs, the Committee of Catholic Society Guidance, Head of KUA (Office of Religious Affairs) and the society involved in the groups of majelis taklim that were fostered by religion counselor, informants who became the data sources, who were then given indepth interviews, and observations of all activities related to counseling.

Unit of analysis, oftentimes called particular research units which were considered as the studied research subjects and the most commonly studied in the domain of social sciences are individuals, family, group, organization, formal-informal social structure. For the context of this research, the analysis unit focused on individuals, namely the religion counselors.

Data analysis was conducted through the following processes: 1) Data reduction by sorting out the unstructured data to become pieces that were more regular by coding them, arranging them into several categories, and summarizing them to become simple pattern and structure; 2) Interpretation, to get the meaning and understanding about words, symbols, and actions of research informants and participants by exposing the concept and theory that explain the research findings; and then, 
to communicate the meanings of the findings through a written report. At the last stage, the data collected were analyzed in a descriptive-qualitative way after going through the processes of coding, categorization, and data display.

\section{FACT FINDINGS AND DISCUSSION Description of Research Locus}

Ambon society has the same genealogical root. They are the native people who inhabit Ambon island, Lease island, the Western and Central regions of Seram, and as the supporters of Ambon culture that is the hybrid, acculturation of Melanesian, Polynesian and Malay cultures (Jacob W. Ajawaila, 2000, p. 16) Uniquely, along with the turn of time with the accompanying social change, Ambon island underwent a very segregated social split based on religion.

Keuning (1973) says, on this Island that was recorded in the travel notes of explorer Ibnu Bathutah as jazirat al-muluk (peninsula of kings), there were two associations (gemeinschaft) that divided Ambon Island into two halves of communities, namely ulusiwa community who inhabited the region of Leitimur Peninsula generally inhabited by the Christian community with the orientation of patasiwa (group of nine), and ulilima community who inhabited Leihitu Peninsula as Islamic lands that were popular with patalima (group of five).

The land or country or land as a community association based on genealogical territory, according to Jacob, was formed based on religion segregation. The Islamic land popularly known in the Ambon people circles as negeri salam (land of peace), and the Christian land as negeri sarani (land of sarani). Then it was understandable enough when an informant (Interview with SL/60 years old, 01 July 2015) understood the meaning of RMS as Sarani Maluku Republic instead of South Maluku Republic (Zud Moluccan). This very segregated pattern of inhabitance made it easier for the colonial Dutch to control the Muslims' activities and movement. When there was a social movement leading to a fight or mutiny, it was easily canalized into its community. Parallel with the significance of land, Ambon people used to locally discriminate the concept of land and State, instead of being related to geopolitical region, it was based on religion difference. The concept of State was often related to contestation, even conflicts between Islam salam and Christianity sarani, Islam was often associated with State while Christianity was made identical with RMS. Meanwhile, the concept of land was more in the sense of Ambon region as the beloved county, without political contents (Abd Kadir Hatib, 2009: p. 287).

The segregated pattern of inhabitance as the result of the colonial social construction in the frame of facilitating the hegemony and control over Islamic social body, gave resonance to social relations, marked with term or title difference, and again the terms were based on religion, the terms Obed and Acang (Hasan) became markers for the social split, although according to an informant (Interview in Ambon, 03 July 2015) the habit of mocking each other between Acan the Muslim and Obed the Christian had a lower tension after the conflict.

Even with a jocular tone probably, one of the young men said that some of Ambon people proudly claimed that South Maluku was the $12^{\text {th }}$ province of Holland. Everything was supported by an assumption that the colonial Portuguese and Dutch were the ones that opened their eyes about modernity. In short, it was the Dutch who "made" the Ambon people savage.

The success of the colonial Dutch to form a discourse about civilization, modernity among young Christian men of Ambon created a world view that they were superior to their brothers who were Muslim. Aminuddin (56 years old) said that before chaos took place, the non-Muslim young men of Ambon were very selective in choosing a job and avoiding a job because they felt so superior that they created their prestige. The jobs they avoided most were those as pedicab becak driver and motorcycle taxi rider, only because of the consideration of dignity, prestige, and keeping their body physical manliness. With a jocular tone, some college students said that prestige and physical control were very dominant among Ambon young people; look at this one of the satirical statements, "it is okay to have pale bones, but never have a pale face", "biar seng ada nasi yang penting bagaya (let me have nothing to eat as long as I get stylish)".

Not only in the corporation of tata ruang, the social physical disciplining became an easy target for the colonial Dutch, one of which was by changing family names of Muslim Arab descendants' for instance, as an effort to blur religious identity and authenticity of indigenous people and at the same time to change those names with colonial identity. This change of family name happened to $\mathrm{H}$. Saleh Lestaluhu, a former bureaucrat in the Provincial 
Government of Maluku, who claimed that genealogically his ancestors came from BaghdadIrak; previously his last name was one of the Arab family names, such as Saggaf, Al-Attas, etc. yet his last name was changed by the colonial Portuguese people into Lestaluhu family name, then it was inevitable that Saleh was also "taken hostage" in the liminality of Komi Bhaba.

Power relations through Christian people's fight who did mimicry (imitation), were even more obvious than those through the young Muslim men, because the existence of Christianity in this region was due to the service of the Portuguese and the Dutch, both of these imperial nations were the ones that introduced Christianity on this homeland of Pattimura, and what even happened was the occurrence of mutually symbiotic relations. Therefore, Bhaha's statement that the colony community succeeding in doing mimicry would be in an ambivalent space called "the liminal space between cultures". (Khomi Baba, 1994; p. 77) Young Christian men of Ambon did mimicry from the life pattern even to the ideology of the colonial people remember the political agenda of RMS that up until now has been a plan to subvert against the national sovereignty-, so it was a popular joke in Indonesia that Ambon people were the Black Dutchmen. Here probably Komi Bhaha's term was related to "almost the same but not quite", or "white but not quite white", although they completely imitated the colonial speech, but they would never be precisely the same.

On the young Muslims' side, there was a joke that marked Bhaha's thesis, that all that time they always imagined to follow the traditions of salaf salih, so the clothing was again imagined to be the clothing of the Prophet and scholars of Salaf Salih, perfected with the beard that added to the "fierceness", then occurred a joke that Ambon young Muslim men were mujahidin (fierce faced, but cool hearted).

Mimicry of discourses and patterns of physical disciplining that were imagined to be controlled by Syar'i (Allah SWT), through His syariat instrument became stronger following the chaos that happened from 1999 to 2001; Muslim females who previously appeared commonly with exposed private body parts suddenly wore clothes of jalabah or jilbab (i.e. hijab, the Muslim female's head scarf) and even some of them seen to wear face covering clothes. Similarly, the Muslim men grew their beard, wearing onepiece long clothing typical to the Middle East, and Pakistan/Afghanistan, and at other times they wore shorter trousers.
Ambon City was categorized as small; in following the steps of development, the city was felt to be smaller and densely populated, because the space and region management tended to be disorganized. This was a city with its quite open people, the city whose population inhabited Ambon City and started to get in contact with modernism during the Portuguese and the Dutch colonialism.

Ambon City in the frame of Spatial and Regional Planning of Maluku Province lies in most of the Ambon island region that aggregately shared a border with Central Maluku Regency, took the slice of provincial territory of $377 \mathrm{~km}^{2}$. Data of statistics state that the aggregate of Ambon City population in the mid-year of 2013 aggregately totaled 379,615 people, increased by approximately $4.36 \%$ from year 2012, and in the previous years the increase was higher. This addition was due to the support of the immigrants who came back, after their previous exodus to their homelands, such as the Bugis-Makassarese ethnic group, and the Buton ethnic group, in order to avoid the chaos that took place in Maluku, that crushed some of their relatives and friends and also the assets that they had left in Maluku.

\section{Social Configuration of Counselor Client}

It was mentioned earlier that in the conflict map in Nusantara (the Indonesia Archipelago), Ambon City was categorized as having a strong potential, both in latent way and manifest way, and that was already recorded in the chapter of Indonesia's dark history of social relations. Historically, there were at least three happenings that influenced -directly or indirectly- the pattern of relationship among religion believers in Ambon City today, namely: 1) from the beginning the two different religion believers met in Maluku, the tension and conflict had already occurred to dominate each other and seize influence, so this city "contained" latent conflicts that at anytime could have exploded if they had not been managed in a prime and accurate way; 2) the Dutch politics of discrimination against the people of Ambon City, gave a priority to the Christian people, especially in the field of education; 3) Movements of the RMS separatist group.

Probably, the politics of devide et impera declared by the colonial Dutch was perfectly implemented in this region. The regional and spatial politics was deliberately and systematically designed to make segregations, physical and non-physical segregations. People of Ambon yang shared the 
same genealogy (Jacob Ajwaila, 2000; p.16) only because of their theological preferences -Islam and Christianity- they were socially split based on religion differences. And then, the inhabitance patterns were also split homogeneously based on the religions that they embraced. Bung Hattas metaphor very accurately described this reality, that what was created was persatean (group of sate) and not persatuan (unity).

\section{Religion Counselor's Performances}

The above-mentioned socio-cultural condition of Ambon people, who became the clients of religion counselors, became a distinguisher among them and their colleagues in other cities who lived in stable and conflict-free conditions. If religion counselors in other places could breathe and live in relief by only focusing on making programs of counseling and becoming conventional counselors as regulated in the above-mentioned regulations, the condition was different from the religion counselors living in Ambon City, "Ambon is not forever as nice as what people think", as said jokingly by one counselor, a typical Ambon man who was rich in jokes. "Up until now," he continued, "We have often seen people who are still haunted by the conflict trauma."

When speaking about the religion counselor's performance from the side of balance, then the problem started here; some informants especially the non-Muslim saw something which was not proportional. This is important if we are still committed to the Malino Agreement that prioritized balance on every line. Then they referred to the population of Ambon City in year 2014, with population aggregate 379,615 people, that increased by $4.16 \%$ from the previous year.

Based on the most recent composition of Ambon City population, dominated by the Christian, truly again, if the reference was distributive and proportional justice then recruitment of religion counselors also needed adjusting. However, it was factually different, which was seen from the data owned by the Ambon City Ministry of Religious Affairs, that there were 21 Muslim counselors who were Civil Servants, 3 Christian counselors but now there were only 2 left because the (main) skilled counselor was transferred to structural position, 1 (one) religion counselor. Meanwhile, there was 1 (one) Buddhist counselor, and also 1 (one) Hindu counselor assigned in Maluku Provincial Office of the Ministry of Religious Affairs.
Problems of proportion and balance among religion counselors seemed quite obvious on the functional position of non-Muslim counselor; from the side of counselors' quality that was really not balanced with the number of population that became their clients and also from the side of counselors' capacity that certainly would have implications on manhaj and the strategy of counseling and guidance that was applied. Further impact on ceounseling activities tended to be monotonous and very conventional.

And then the problem of culture difference including the internal culture of organization where the counselors work, the organization that relatively still applied closed management, the counseling that still confronted with paternal-structural-faomal culture in the common communication pattern between the counselor and his superior that was still formal and structural.

These religion counselors were distributed in some working units, some counselors were at the Ambon City Ministry of Religious Affairs, such as Muslim counselors who mostly worked at KUA (The District Office of Religious Affairs) for the working region of Ambon where ideally each subdistrict had its definite office of KUA. However, until today only three sub-districts had KUA, yaitu: KUA Nusaniwe, KUA Sirimau, dnd KUA Baguala. The existing KUA also still had no asset of their own, such as KUA Nusaniwe which still borrowed spaces at one of the Offices owned by the Provincial Government of Maluku. That KUA was previously operating in Waihaong, yet after the conflict the office could practically not function again, because it was said to be in the non-Muslim's region, very dangerous for the KUA staff to still work in that region. Therefore, the solution was moved to the above-mention temporary place.

Therefore, when averaged, there were 6-7 counselors at every KUA. This was negatively correlated with the existence of penghulu or marriage official; up until now, there had been only 1 penghulu in Ambon City, working at KUA Sirimau, because this sub-district was categorized to be the most densely populated, so the number of marriages was very high. Nevertheless, according to several counselors, the limitation was partly overcome by the religion counselors: as some of the penghulu's jobs and functions were actually relevant with the counselors', for example guidance and courses for bride and groom to be and marriage advise, etc. 
From the side of counselor's intellectual capacity, it could be considered as adequately good, because on average the counselors had achieved the undergraduate degree or Sarjana, and one (Christian) counselor had achieved master's degree. Career development and education progression also became the expectation that needed attention in order to build a new hope for potential and successful counselors who were capable and creative. The counselor's profession seemed to halt at the religion counseling job, without being given an opportunity to have a career in structural position.

After the interviews with some counselors, including Ustadz Sofyan, Head of Fokjalu of Ambon City, the counselors' expectation was to see the Government agenda to give every counselor opportunities to increase their capacity and competence through formal education and training or orientation. The counselors stated that the development of human resources as counselors became absoluteness, in the frame of keeping up with the progression of aspirations and needs of the general public who became the counselors' clients.

\begin{abstract}
According to Fatimah, the national best counselor, the government should understand the presentday actual condition, where the general public were easily got access to information, this reality encouraged them to become more critical and information-literate, especially in the urban area, this condition made it absolute for the counselors to make an adaptation process so that they did not have less information than did their clients. The public started to lose interest in monotonous and monolithic counseling pattern in the form of preaching only.
\end{abstract}

The transformation of Ambon City people described by the above counselor was in line with the prediction of Granovetter (Dieter-Evers, 1988: 73), the public's life pattern had changed and shifted from the previous orientation of market share to globalfree-market (global market). The shift of this basic pattern obviously would affect the public's sociocultural life. Next, the counseling implementation would deal with the public's culture which in general started to be infected by the pragmatic, materialistic characteristics, and tended to consider the issues of religion counseling as less important (Ramli, 2006: 57).

Some knowledge disciplines were urgently needed to be given to religion counselors, for example counseling management, intercultural communication, especially the communication with communities of different religions, such as those in Ambon City, this kind of knowledge really would help to ease the work activities of the counselors. The significance of reinforcement of religion counselor's capacity was described by one of the informants, Nur Azisah Nuhuyanan, as follows:

Muslim counselors as the executors of religion counseling activities have a very important role. Because talking about religion counseling means talking about the public's needs with all their problems. What we see in the society, what we feel from their behaviors, the magnitude of effect to the believers and other religion believers in terms of living harmony, we the counselors have to be responsive and understanding, because this has been our job responsibility.

A Muslim counselor has to have capabilities as a reliable counselor who is not only a fluent speaker in preaching. Besides that, a counselor also must be capable of applying a learning method that is human and effective in the process of transforming his teachings and religious values to the society so the society can feel the benefits and apply them in their own life and the believers' life.

Regarding the counseling management that up until now were still not yet optimally given to the counselors and caused them to have performance whish was not well structured and managed, they tended to still work sporadically. On average they only focused on giving guidance which was very conventional, and it was also only to serve the groups of majelis taklim and TPA, they were not yet creative and progressive in doing social-religious which were more crucial, for example to advocate Ambon people who were still quite segregated extremely, and the worse thing was that their inhabitance pattern was limited based on religion and ethnicity.. The point was that the management of counselors and counseling was still very weak and not yet professional.

The counselors' performances were relatively adequate when observed from their report of performances. The implementation of counseling activities in Ambon City according to the regulations was started with preparing the work program for counseling objects in line with the needs of every counseled individual citizen. This work program then became a reference in the process of implementation of counseling activities. 
Next, the counseling activities and work program were reported to be evaluated by the Office of the Ministry of Religious Affairs in Ambon City.

As sub-urban society members were generally busy with economic ectivities in goods and service businesses, the community religion counseling became very important to encourage the growth of dynamic religious condition. Religion counseling was also very urgent in supporting the creation of Human Resources Quality that made the religious values and teaching as a guide in the community's daily life, especially in their work and when they live in a society.

As sub-urban society members whose life was busy with work activities, they became fragile and tended to neglect religious values and teaching because of their limited time, opportunities, and religion teaching media that lack access to the understanding of religious values and teachings. Therefore, it was very understandable that the society's religious understanding, appreciation, and practices were very limited, even those which were at the basic level.

This thing made it absolute to have needs for religious counseling activities in order to give awareness to the general public about the importance of practicing the religiuos values and teachings by giving them teachings and understanding about the basic themes of Islam, such the issues of belief, prayer, fasting, purification, Alquran literacy and recitation, and other Islamic basic themes. Similarly, at the level of young children who really need the presence of a religion counselor with a role of a religious teacher and counselor for children starting from Alquran recitation classes at TK/TPA (Kindergarten/ Alquran Recitation Schools) and madrasah diniyah (Islamic kindergarten). Besides being a religious teacher and counselor, the counselor also had a role in solving various problems faced by the general public, especially the problems related to religious problems.

Based on the interviews with two religious counselors (who were Civil Servants) working in Ambon City, they both dominantly stated that in making their counseling work program, they involved the community members who became their counseling objects and observed the priority scale of the community members' needs. Every counselor was responsible to the community members that became their counseling objects. As regulated, every religious counselor who was Civil Servant was responsible to serve 4 groups of counseling in line with the counselor's rank level, while every religious counselor who was a part timer or not Civil Servant was responsible to 1 group that became his counseling objects. The community groups who became the counseling objects were formed based on the initiative of a counselor who then gathered the community members in one medium. Also, the community groups who became the counseling objects were formed based on the initiative of the community members themselves who then formed groups of Alquran recitation or majelis taklim to where a religion counselor would come to make the groups his object of counseling. The groups becoming the objects of counseling Ambon City, relatively homogeneous, were majelis taklim whose participants were dominantly women.

Meetings held in the frame of routine counseling were once a week, in a form of Alquran recitation or pengajian. For their counseling groups, the counselors played the role of the counselors who were worked to make a curriculum and schedule of counseling, although more often the preaching work was done by another ustadz/ustadzah, especially the preacher from the committe of another religious organization in Ambon City. However, for that particular counseling group, Ustadzah Azizah always allocated her time to attend in the group herself, at least once a month in every group of majelis taklim. Every counselor made a work program as a reference in counseling the objects of counseling. Activities of the work program carried out included group members upgrading, for example through preaching and Islamic discussion, classes of reading and writing Alquran, and worshipping practices. Besides, there were also other activities to support the counseling activities, such as group prayer or zikir, recitation of the Chapter of Yasin, and also activities of consultation about religious issues.

Every counselor was fully responsible to design a work program based on the needs of every object of counseling. In counseling the community members, who became the object of counseling, a counselor desgined matters that would be presented in the activities of pengajian or preaching. Activities of pengajian and routine upgrading for the group that became the object of counseling were done routinely and regularly. For the group of pengajian and majelis taklim, the counseling and upgrading given to the group were pengajian and preaching done routinely at least once a week. Even in practice, the activities of counseling and upgrading were done a few times a week. Every month the two counselors 
intensively gave their reports of counseling activities to the Section of Penamas in the Office of Ministry of Religious Affairs in Ambon City.

The matters generally presented in the counseling activities done by Ustadz Khairul and Ustadzah Nur Azizah in the region of Ambon City, the implementation of counseling in Ambon City as regulated started with the making of work program for objects of counseling in line with each community member given the counseling. The work program then became a reference in the process of counseling activity implementation. Next, the counseling activity and work program were reported to be evaluated by the Office of Ministry of Religious Affairs in Ambon City.

As sub-urban society members whose life was busy with work activities, they became fragile and tended to neglect religious values and teaching because of their limited time, opportunities, and religion teaching media that lack access to the understanding of religious values and teachings. Therefore, it was very understandable that the society's religious understanding, appreciation, and practices were very limited. This thing made it absolute to have needs for religious counseling activities in order to give awareness to the general public about the importance of practicing the religiuos values and teachings by giving them teachings and understanding about the basic themes of Islam, such the issues of belief, prayer, fasting, purification, Alquran literacy and recitation, and other Islamic basic themes.

Similarly, at the level of young children who really need the presence of a religion counselor with a role of a religious teacher and counselor for children starting from Alquran recitation classes at TK/ TPA (Kindergarten/Alquran Recitation Schools) and madrasah diniyah (Islamic kindergarten). Besides being a religious teacher and counselor, the counselor also had a role in solving various problems faced by the general public, especially the problems related to religious problems.

Based on the interviews with two religious counselors (who were Civil Servants) working in Ambon City, namely Abdul Karim and Ustadz Wahab they both stated that in making their counseling work program, they involved the community members who became their counseling objects and observed the priority scale of needs of the community members who became their counseling.
Every counselor was responsible to the community members that became their counseling objects. As regulated, every religious counselor who was Civil Servant was responsible to serve 4 groups of counseling in line with the counselor's rank level, while every religious counselor who was a part timer or not Civil Servant was responsible to 1 group that became his counseling objects. The community groups who became the counseling objects were formed based on the initiative of a counselor who then gathered the community members in one medium. Also, the community groups who became the counseling objects were formed based on the initiative of the community members themselves who then formed groups of Alquran recitation or majelis taklim to where a religion counselor would come to make the groups his object of counseling. The groups becoming the objects of counseling Ambon City, relatively homogeneous, were majelis taklim whose participants were dominantly women.

Counselors were also fully responsible to design a work program based on the needs of every object of counseling. In counseling the community members, who became the object of counseling, a counselor desgined matters that would be presented in the activities of pengajian or preaching. Activities of pengajian and routine upgrading for the group that became the object of counseling were done routinely and regularly. For the group of pengajian and majelis taklim, the counseling and upgrading given to the group were pengajian and preaching done routinely at least once a week. Even in practice, the activities of counseling and upgrading were done a few times a week. Every month the two counselors intensively gave their reports of counseling activities to the Section of Penamas in the Office of Ministry of Religious Affairs in Ambon City.

The complexity of problems faced by religion counselors caused them to always upgrade their knowledge competence and capacity, it was not without challenges, because they worked hand in hand with various parties or circles to mutually strengthen so that they could be consistently developing people who are great and have better character. The government gave us the functional position as Religion Counselor, the position that really represented the institution of the Minsitry of Religious Affairs. This position was mandated not only to Civil Servants who were Muslim, but also to Christian Religion Counselor, Hindu Religion Counselor, and Buddhist Religion Counselor, who became assets from the side of human resources 
of this country, that thing was truly understood by religion counselors, as also presented in the following Ustadz Khairul's following description:

We as the service givers on the front guard of the Ministry of Religious Affairs have tasks and functions to give counseling, guidance, giving information and motivation for the implementation of the government's programs, by using religion language. The Program of Government (especially Ministry of Religious Affairs, and other Ministries/Institutions/ Agencies) becomes our responsibilities to pass on to the general public through religionbased communication. The existence of counseling groups here and there, from majlis taklim in mosque/mushalla, prisons, Dharma Wanita (Women Civil Servant Association), PKK, mental counseling in the communities of child generation, teenagers, to senior citizens, Offices/Agencies,, TPQ, Pesantren Islamic Boarding School, are our main fields in executing our tasks given by our beloved state and nation.

Besides strengthening the intellectual capacity that was still very scarcely given or allocated for the religion counselors, what added to the many problems clinging on the counselors were work facilities and infrastructure, because so far they did not yet get facilities of transport that was a supporting factor in carrying out their duties and functions. Every day they gave guidance and counseling in their respective counseling region by using their own money. Therefore, for the counselors the expression of empathy could be in a form of allocation of operation fund to cover the operational cost in doing their Civil Servants' counseling activities, where in other ministries, the fund allocated had been increased a few times; whereas the fund allocation for religion counselors had never been given at all.

Ironically, every day the counselors were in the field, while the functional allowance they got every month was not sufficient, especially in Ambon City where prices of things were high, the counselors' allowance so far had not been increased. There was a need for allowance increase for functional position, because the allowance had never been increased since year 2007. Whereas counselors in other Ministries and/or other government agencies, such as Family Planning Counselors in BKKBN, Agriculture counselors in the Ministry of Agriculture and also the Forestry counselors had been given allowance increases at every level and the increases were even a few times higher, as regulated in the Government Regulation Number 100 year 2012.

Through observation, the above claims of counselors were confirmed, during my several-day visit to KUA Sirimau, and every day, the person who were very responsive and proactive to accommodate the sharing of problems from the general public were counselors like Ustadz Wahab and his colleague, strating from the issues of Syiah, ISIS, to cheating. Besides, a few times interview appointments had to be called off because suddenly the counselors advocated his clients, including the fact that for several days Ustadz Wahab had to go here and there to accompany a client to the Religious Court as the client was in the process of divorce.

If Muslim counselors "celebrated" the adequateness of personnel so their workload could be distributed relatively well, the different condition was found among non-Muslim counselors, who were still having trouble serving and fulfilling the religious needs, where the majority of them Christian counseling clients. In fact, there were only two counselors available. Problem of denominations among Christian people who were more than 100 people also contributed to the problem of counseling. Unlike other religions, responding to the Christian clients needs consideration of denomination problem, where the denominations were respectively different, in terms of liturgy and church. The Christian counselors were not as flexibly able as the as were Muslim counselors in entering places of worship. Josep, for example, was only open to give guidance in GPM (Protestant Church of Maluku) categorized as a large church, while another Christian counselor like Alfananti presently focused on giving her service in Bethlehem Church, both of the counselors could meet only in religious activities if the activities were seminary and ecumenism. This denomination problem would be the biggest constraint when we talked about the fulfillment of Protestant Religion Counselors.

Jose Rizal, Catholic Religion Counselor, had the almost-identical constraint as he was the only Civil-Servant Counselor giving guidance services to Catholic, he also presently concentrated on giving services in Cathedral Church of Maluku, while seven churches did not yet get the Government's services, although admitted that the problem of lack of Civil-Servant Counselors could still be handled by pastors, and everything had been organized professionally. 
The difference related to the fulfillment of counselor personnel in every religion implied their difference in responding to the discourse about the need for specialization and diversification of counselors. Among Muslim counselors, they agreed with the discourse, for the reason of professionalism. Today, they worked partially, did not focus and even worked sporadically, so the performance was not easy to measure, not to mention the increasing workload in KUA (the KUA office) to overcome the lack of penghulu personnel.

On the other hand, different perspective occurred among non-Muslim penghulu, with the same tone, they still objected to the discourses of specialization and diversification, with an alibi that there were lacks of penghulu personnel here and there.
Do not yet speak about specialization and or diversification for the context of Christian counselors. What is urgent to do now is the recruitment to overcome the unbalanced amounts of counselors that still becomes a constraint in giving prime service in the field of religious guidance. The discourses put forward in the middle of scarcity like this are not realistic. Yes, for the number Muslim penghulu that has reached the quota, it is all right to discuss about the counselor's specialization.

\section{The Contribution of Conselors for Living Harmony}

\begin{abstract}
"It is not part of our duties and functions, but although it is not the counselor's tupoxy, indirectly we feel that we still contribute to building the harmony although it is very normative, somehow, the teachings of love and world peace that we have attached in our counseling material are part of the human beings' purpose in embracing and in living as a nation, (Interview with Ibtahim, Ambon, 02 July 2015).
\end{abstract}

That was some clever and pertinent answer from 5-6 Muslim-Christian-Catholic counselors whom I met at their work places in the Office of Ministry of Religious Affairs in Ambon City and I asked them to discuss about the living harmony among different religion believers which was in fact part of their "working". I attempted to understand that answer, using the information I got from the office where from the beginning some counselors had discussed that issue.

I did not give up hope to find related information further. And of course, a few days afterwards, there were always counselors to give information regarding the indirect roles of religion counselors in building the harmony, conflict reconciliation to be exact, after the city that they so far enjoyed was suddenly ripped and torn by the ethno-religious-based conflict. Starting from the certificate shown by Alfananti, the pretty and friendly Christian counselor, as a written proof of her participation, and the participation of several other counselors, in the training activities for interbeliever harmony held by the Religious Education and Training Office in Ambon in the year 2013, where the participants were the religion counselors in the Working Unit The Maluku Provincial Office of Ministry of Religious Affairs.

Nevertheless, because of budget limitation,
according to the Head of Islam Broadcasting
Section, that did not involve all counselors, the
Religious Education and Training Office only
invited the counselors in Ambon City and its
surrounding. Besides, to reach the districts/cities
outside of Ambon it the transportation cost was
pretty high. Even, at particular times the ticket
was more expensive than the ticket to Jakarta.

Unfortunately, the follow-up action, which in fact became the best practice from that education and training was not continued with a program of action facilitated by the government, not through program actualization medium and or the material of education and training about inter-believer harmony, and in a proactive way it was designed to be part of credit point to be judged for a counselor's position promotion. It was commonplace that after education and training, the counselors and the education and training alumni "turned around" to focus on their conventional duties and functions. It was already regulated that a counselor had duties to give guidance and counseling, so they got to focus again about TPA and Majelis Taklim that became the objects of the counselor's counseling. Somehow, it was the only one to be used to propose for a functional position promotion, said Ustadz Haris.

Whereas, if the local government and or action plan making-centers which were integrated with their main duties and functions of religion counselor, would be very beneficial for the government itself, the public, and of course the counselors. To justify the explanation provided, Ustadz Sofyan mentioned some materials he got during the education and training, and in his opinion, it was a pity if it was not applied, especially for Ambon City. 
We were presented this topic about: the Government's policy concerning the living harmony among religion believers, harmony concept, ethics of harmony among believers, analysis of handling and preventing a conflict, techniques of handling and reconciling a conflict, integration factor of religion believers, causing factors of conflict among believers, code of ethics of religion broadcasting, Joint Decree of Ministersi Numbers 9 and 8 about Erecting a Worship House, that was the explanation of the Head of Fokjalu Ambon City.

The role and performance of counselors in the field of harmony were institutionally not yet optimal because the support from the government was still only for the harmony in the religious education and training office. However, there were some progressive counselors who had a voluntary commitment to keep giving contribution; let's say Ustadzah Fatimah, the counselor who was active in Maluku Fatayat NU and who was once the national best counselor, although it was sad that up until today she had not received the award motorcycle promised by the government as a prize. This quite active woman, claimed that she often got involved in some activities related to conflicts and interbelievers harmony done by some NGOs at the local and national levels, such NGO Tifa, a program facilitated by The Habibie Centre that was an attempt to build a dialogue society based on local wisdoms.

Because according to him -and that was in line with the confession of one national TNI soldier working in Kodam Pattimura- necessary to be known, that the peaceful condition in Ambon was supported more by the awareness of Ambon society untuk to end the conflict, not because of a peace program or policy from the third party, including the Government. Well, along with the awareness of reconciliation potential, the thing that was urgent to be done was revitalization of cultural values that were previously the binding ties among Ambon people.

And this proved to be very effective, the examples that were still popularly discussed were the two communities of different religions in Wayame Village which was sterile from the very escalating conflict. After some tracing back, it turned out that the local wisdoms were still functional. Again, that was due to the public awareness to be harmonious in their differences (agree in disagreement). In Ambon City cultural dialects "fighting happens, because different variables are only temporary emotions, even the young people used to mock each other by using the titles Obed (Christian) and Acan (Muslim), but it was always neutralized". Thanks to the local values that were relatively still functional to manage the social cohesion, borrowing Peter L. Berger's theory of sacred canopy, the cultural values were still obeyed as sacred canopy by Ambon society.

Nevertheless, along with the social change, the values that brought a particular ideology and interest that broke into the Socio-cultural building of Ambon people would automatically moved the existing values presently held by the community, and the starkest were the elders of tradition, religion, and the public figures in general who so far had been primus inter pares, becoming a dam that accommodate ethical values suddenly could not handle the huge flow that came to oppress, some were taken away by the push of the flow, so the culture root where the community held onto was almost completely washed away. Although inevitable, the dismantling of tradition figures' authority was systematically not a new thing, but long before, was already done by the New Order regime, through infrastructure uniform politics until the local level, just look at the lands of Ambon with their kings, which were unexpectedly changed by village nomenclature, urban village head, etc. the things that were alien to Ambon people.

Taking the experience of conflict with its devastating power, some counselors like Ustadz Ibrahin Rahawarin and Ustadzah Fatimah had committed to get involved actively in activities related to the attempts to build social harmony, especially inter-believers harmony in Ambon City; to try to revitalize the local wisdoms; Pela-Gandong, basudara, sasi darat and sasi laut. But unfortunately, the counselors only stood on the positions of participants, and not actively involved holistically since the process of program design planning.

The skills and commitment of some religion counselors to participate in the government program socialization activities through religion language, outside of their routine and conventional tasks as mandated to them by the State were used more by other institutions, and they became more productive by doing so rather than only by teaching at TPA/TPQ and majelis taklim; see for example, Ustadz Sofyan, Ustadzah Fatimah, Ibrahim Rahawarin, they quite actively socialized the government regulation, the efforts to overcome terrorism at BNPT of Maluku Province, socialization about dangers of narcotics 
at $B N N$ of Maluku Province, the program of Family Planning in $B K K B N$ Maluku Province, including their involvement in giving guidance at Polda and Kodam Pattimura Maluku.

\section{CONCLUSION}

In a macro way, Ambon in the observation of religion counselors was already condusive, where social and economic life already moved again. Public spaces were merrily used by a lot of people from various primordial backgrounds, each of whom with the intention to routinely meet to make economic transactions, to discuss and deliberate social, economic, and political issues starting from light parody similar to stand up comedy to local and national political analyses. Although it was undeniable that here and there rigid patterns of communication and addressing among people were still seen. It was a natural thing in the place where society was still in the process to wipe the conflict trauma.

It was acknowledged by some circles, that for the context of Ambon, conflict handling and resolution in a comprehensive and permanent way leading to co-existence, even if possible until the level of pro-existence among religion believers in Ambon, was not an easy matter. The ethnoreligious case strongly rooted, even since the two different religions met for the first time in Ambon, the different believers also immediately stood in binary positions, with the shields of minhum (they) and minna (our people)-even until this research was conducted, these terms were still commonly heard-.

Encountering this kind of social reality became the homework of everybody who got the mandate from the State, to keep deliberating their services to the community that became their clients. As the provider, each counselor should truly prepare whatever became the public's need, including the effort to ensure the creation of harmony among different believers, which was from the beginning already set as part of a favorite program made by the Ministry of Religious Affairs. Unfortunately, the thing that showed up was chaotic, considering that the religion counselors who were on the front guard deliberating the development services in the field of religion were only capable of arranging activities, which in the context of Ambon, there were still things to be the priority scale to be handled by religion counselors, namely to ensure that social cohesion among religion believers became stronger.
Therefore, it was a very progressive thing when Islamic religion counselor came up with the offer to re-arrange a counselor's functional position which was never yet made clear, in order to be more professional, and the counselor's performance was more measurable. So, there were needs for diversification, specialization, or departmentalization, or whatever the name was. It was directed that there were functional religion counselors whose particular specialization was in the field of harmony among religion believers, counselors of zakat and wakaf, etc.

Specialization also became the expectation of all non-Muslim counselors, based on the performance reason that was more measurable and capable of being professional. However, according to them, the urgent need was the availability of professional counselors that were proportional with the number of believers that had to be given religious services first. After the urgent need was fulfilled, then specialization became absoluteness.

\section{ACKNOWLEDGEMENT}

Thanks to the Chief of Religion Research and Development Board; to all senior researchers, informants as data sources, and others. Following their advice and support led to a lot of improvements and achievement until the research results were obtained.

\section{BIBLIOGRAPHY}

Ajawaila, Jacob W. 2000. "Orang Ambon dan Perubahan Kebudayaan” dalam Antropologi Indonesia, No. 61, 2000.

Bawollo, Robert (Ed). 2010. Si vis Pacem, Para Dialogum; Ziarah Bersama Agama-Agama Abrahamik, Mencari Akar Kebersamaan, dalam Menggugat Tanggungjawab Agama-Agama Abrahamik bagi Perdamaian Dunia. Yogyakarta: Penerbit Kanisius.

Creswell, John W. 2009. Research Design: Pendekatan Kualitatif, Kuantitatif dan Mixed (Terj). Yogyakarta: Pustaka Pelajar. 2014. Penelitian Kualitatif dan Desain Riset: Memilih Antara Lima Pendekatan (Terj), Edisi III. Yogyakarta: Pustaka Pelajar.

Daymon, Christine and Immy Holloway. 2008. MetodeMetode Riset Kualitatif dalam Public Relations \& Marketing Communications (Terj). Yogyakarta: Bentang.

Kadir, Hatib Abd. 2009. Bergaya di Kota Konflik. Yogyakarta: Pustaka Pelajar.

Lubis, Saiful Akhyar. 2007. Konseling Islam. Yogyakarta: eLSAQ Press. 
Miles B, Matthew, and Michael Huberman. 1992. Analisis Data Kualitatif: Buku Sumber Tentang Metode Baru (Terj.). Jakarta: UI-Press.

Mujiburrahman. 2008. Mengindonesiakan Islam: Representasi dan Ideologi. Yogyakarta: Pustaka Pelajar.

Munir, Muhammad, et.al,. 2012. Manajemen Dakwah. Jakarta: Kencana Predana Media.

Nugroho, Riant. 2014. Metode Penelitian Kebijakan. Yogyakarta: Pustaka Pelajar.
Pip Jones. 2009. Introducing Social Theory, diterj: Achmad Fedyani S: Pengantar Teori-Teori Sosial: Dari Teori Fungsionalisme Hingga Postmodernisme. Jakarta: Yayasan Obor.

Rumahuru, Yance.Z, et.al,. 2010. Paradigma Transformatif Masyarakat Dialog. Yogjakarta: Pustaka Pelajar.

Wahid, Abdurrahman. 2004. "Hubungan Antar Agama, Dimensi Internal dan Eksternal di Indonesia", in Elga Sarapung, et.al (ed): Dialog: Kritik dan Identitas Agama. Yogyakarta: Pustaka Pelajar. 